DOI: 10.2478 /ausfm-2014-0028

\title{
Harmony of Senses - 3D Documentaries of Herzog and Wenders
}

\author{
Katalin Turnacker \\ University of Pécs (Hungary) \\ E-mail: turnacker@vipmail.hu
}

\begin{abstract}
The two still active great artists of the new German cinema, Werner Herzog and Wim Wenders, presented their 3D documentaries on the 2011 Berlinale. This coincidence, not to be neglected in itself, is more than a mere experimentation with the new technology. Indeed, it much rather reveals the complexity of perceptions coming into action during the film experience and their relationship with the onlooker. It highlights the process in which the viewer involuntarily, thoughtlessly relates to their own sensory experience. Following their feature films grounded on the visuality of the cinema experience indicative of the German New Wave, the two directors now created a documentary which draws on the synthesis of various senses and a viewer's position focusing on perception and interpretation. This paper proposes to analyze how the harmony of senses happens on various levels, from the application of visible, audible, tangible subject motifs and modes of expression asking for various forms of perception, and all the way to the directorial perspective focusing on the viewer's engagement.
\end{abstract}

Keywords: Wim Wenders, Werner Herzog, 3D documentary, perception in cinema.

\section{Introduction}

The $61^{\text {st }}$ Berlinale (2011) celebrated with great interest the featuring of 3D technology into the festival program. On the "day of spectacle" the two world famous masters of the German new wave, Werner Herzog and Wim Wenders presented their most recent documentaries produced with 3D technology. The first projection was Wim Wender's dance film, a memorial documentary about the tragically deceased choreographer, Pina Bausch, followed at the end of the evening by Herzog's film on the ancient paintings of Chauvet Cave in southern France, as a cinematographic "State of the Art." Going beyond 3D mainstream-movies, the two films stood as evidence for the artistic employment of this new technology. 
The innovative potential of new media lies in the fact that, by abandoning the analog perspectival image space, it brings about the transgression of the usual boundaries, the possibility of opening towards the audience, and the elimination of the viewer's distance or physical separation. This consensual statement is based on technological, as well as ensuing esthetic and historical antecedents. Let us know set aside the 3D-experiences of film historical periods and highlight the innovation of the 1990s, the wide use of the flat screen, which in fact affected the depth of the view. The glass which separated the real from the unreal limited the movement of the gaze, and made it only possible to work in one single direction, in accordance with an analog single-channel medium. This conspicuous shortage in space experience and the restriction of the gaze brought about the need of a radical change in function: the desideratum of medial feedback and implication. The focus was shifted from audiovisual information to perception, eminently touching: the level of previous separation has now become a surface of tactile interaction for this new medium. The viewer's distance has diminished, its material separation ceased, and the images began moving towards him in the whole depth of the space, encircled him, penetrated his instincts. Now nothing prevented the viewer from literally taking into his hands the setting of the order of images, their montage, and their manipulation in time, space, or subject matter (Freyermuth 2011).

From that time on one could witness a rapid dissemination of digital technology and new media visuality, which radically reshaped all three segments of film industry (production, distribution, and presentation). As a result of the rapid reaction of mainstream-cinema, the pre-eminent genres became fantasy, thriller, and mainly animation. However, one can also often find that directors who started their career in the time of European new wave cinemas, consider digital technologies as a new instrument for the innovation of the art of film. Wim Wenders thinks it works as insurance for the future of documentary filmmaking, as a re-discovery of early cinema. ${ }^{1}$ This claim can be understood as a re-discovery of the classic experimental silent movie, but it can also refer to the esthetic quality of the new waves. Wender's recent documentary presenting the art of Pina Bausch contains references to both of these aspects, completed with focuses on the position and perception of the body and space on and in front of the canvas. In this sense Werner Herzog also chooses not to place the emphasis in his 3D film

1 See: Wim Wenders über seinen Film "Pina" http://www.stern.de/kultur/film/ wim-wenders-ueber-seinen-film-pina-ich-dachte-ich-kann-es-nicht-1657549.html Last accessed at: 2012. 01. 14. 
on the intense technical work, but on the reshaping experience and effect that strikes the person who steps into the cave: man's awaking to life, his most ancient environment as mediated by paintings. ${ }^{2}$

\section{Preliminaries}

The formation of sensorial cinema bearing archetypal features raises a series of cultural, artistic, and philosophical questions, for the discussion of which it is worthwhile to survey the theoretical and historical preliminaries present in the life-work of German directors. Béla Balázs was the first of the theoreticians of film language to raise the problem of immersion. It is due to the so-called creative camera that we see differently than in reality, as long as the emergence of closeups and details helps us situate ourselves right in the midst of the events. As a result of its mobility we can experience over and over again the dynamic changes of perspective, as the recorder has done away with the distance of the viewer, "which has been the essence of visual arts before" (Balázs 1984, 131). The viewer does not feel excluded from the closed world of art, but becomes part of the relationships, feelings, or thoughts of the visible person. Of all arts, Béla Balázs attributes this singular ability to the film alone, an ability which is formed by the purposeful application of film language apparatus.

Continuing this direction, the ideas of classic realist theoretician Siegfried Kracauer (1964, 320-330) must be mentioned, who considers the mechanical seizure of real images, the representation of the changing world of physical existence the basis of filmic spectacle. The mode of expression based on the primacy of seeing becomes characteristic of cinematography if the ideology, the content of the inner world gets in the background. Reality is manifested by various elements and conglomerates, in hardly noticeable surface phenomena which play an essential role in a film-like plot. With the recording of the visible world (whether real or imaginary), films offer solutions for hidden intellectual processes, historical facts, the state of a society, or the characteristics and dreams of a nation; the decoding of this spectacle can be referred back to the field of social reality. Kracauer's theory presumes the primacy of the sense of seeing; still, the emphasis of factual, material features implies the necessity of the sense of touch. Of all German new wave directors, it is the life-work of Werner Herzog

2 See: Erholung ist, den Gegner von Tom Cruise spielen http://www.welt.de/kultur/ kino/article13691405/Erholung-ist-den-Gegner-von-Tom-Cruise-spielen.html Last accessed at 2012. 01. 14. 
that can best be connected to this concept, and this is also the starting point of his new documentary, whose title (The Cave of Lost Dreams) can as well be conceived as a reference to Kracauer's theory.

The cinema of the physically based realist theories is connected and completed with the emphasis of movement, which Erwin Panofsky calls "the dynamization of space" (quoted by Kracauer 1999, 12). The immobility of the viewer while he watches a film should only be understood physically, whereas in an esthetic sense he is in constant movement. Since the eye identifies itself with the lens of the camera, the direction of gaze and the distance are in constant change accordingly. The fictional space represented for the viewer is just as much in movement as the viewer himself. It is not only the body fixed to its place that moves in space, but the space itself changes, revolves, falls apart, and rebuilds again. By this recognition the researcher analyzes the position and nature of the viewer's implication also from the point of view of seeing; nevertheless, it can be regarded as an important milestone in the formation of the experience of cinema. The difference between perspective view and trompe l'oeil paintings had displayed the formation of spatial dynamics long before the birth of film. While in Alberti's system the viewer is disrupted from three-dimension reality and is fascinated by the two dimensions of the painting, the Baroque painting style based on the conscious hoax of seeing moves the view and its spectator in the space of image, stepping out of the plane. This latter style does not employ the instruments of pictorial illusion, but draws into an imaginary world with the help of senses.

The perception of seeing has long been considered most important in the formation process of immersive experiences, since it plays a dominant role in the recognition of objects and people. In contrast with this restrictive, hierarchical concept of perception, another view emerges, building on the complexity of seeinghearing-touching, and not less that of body perception and its analysis, spectacularly demonstrated by the 3D works of the German directors. Visual perception therefore cannot be regarded as exclusive or exhaustive, since information gained by touch is also necessary for the differentiation or identification of things. It is also indisputable that touching plays a leading role in human development and interaction, while it is also a universal means of interpersonal communication. The tactile message is one of the general features of Homo sapiens, and is dependent on human culture. In Western Europe for example the unwritten rules of contact were transmitted to subsequent generations, and are mostly widely known. In some cases a perception gained by the sense of touch can be more reliable than seeing. The stimuli of the several thousand mechanoreceptors of the skin and 
the fingers and the muscles which move the fingers have a role in the formation of tactile features. The insecurity of touch can even be a matter of life and death: blind and deaf people see with their hands, they sense the vibrations formed during speaking by touching the speaker's face. ${ }^{3}$

In connection with haptic perception, writers of ecological film theory pay special attention to the biological process of tactile perception or active touch. When fingers smoothly touch an object, certain tactile signals are formed which guide the further movements, then the new signals formed result again in further movements. According to James Gibson's (1966, cited by: Sekuler-Blake 2004, 437) remark the actions made with the movement of body parts and fingers can change the objects touched, and even the perception itself. The information coming from the nerve terminals of the skin is combined with different information, kinesthesia, the receptors of which, located in muscles and articulations, inform about the position and movement of the members. Tactile and kinetic information is inseparable; consequently any sensory signal which is equally dependant on tactile and kinesthetic perception is called haptic perception. Gibson claimed that haptic capacity has not been appropriately recognized due to the dominance of visuality and the motor dexterity of the hand. However, in cases when one cannot see, objects can still be well recognized only on the basis of haptic perception. Visual experience is not a necessity therefore in bringing together tactile and kinesthetic information, thus the exploration of spatial organization of people born blind is similar to those who can see.

In the case of film the creators employ the multiple images and orders of seeing, sight, or visibility, and the viewers, who are participants of the spectacle and at the same time viewers of their own participation, are subject to influences created by these (illusion, manipulation, deception, a sort of supervision, etc.). Cinema has multiple ways of reflecting the blockages and aporias of seeing, of the gaze, by, among others, not being satisfied merely with revealing visuality and its contradictions, but also employing other forms of perception in the process of film creation and reception. Synaesthesia, intermodality, and the theories of phenomenology are fields which deal with the interplay of senses, the complexity and physicality of perception (Elsaesser-Hagener 2007, 139). Going beyond the criticism of visual dominance, Vivian Sobchack (2004, 55-84) places the analysis of the complexity of skin and body perception as a uniform communication surface in the foreground of film theoretical thinking.

$3 \quad$ Herzog treated this issue in detail in his documentary entitled Land of Silence and Darkness (1971). 
Looking at the life-work of the two German directors, it is conspicuous that ever since their earliest films the immersive feature was always present in addition to the complexity of perception and the uniqueness of audiovisuality. One reason of this similarity is that they both learnt the art of filmmaking in the cinema, from where they borrowed their subjects, sources, generic and stylistic characteristics. German film history in the late 1960s - early 1970s (1971/1972) witnessed the formation of a multitude of esthetical principles, visual forms and patterns, and last but not least the methods to be applied for the captivation of the audience. The films are mixed in style: they equally contain narrative patterns and instruments characteristic of European art film, the exemplary fables and positive heroes of popular films, as well as the extension of fiction film towards documentaries. This is the beginning of the careers of the three directors recognized both in professional and connoisseur circles: Herzog's Signs of Life in 1968, Fassbinder's Love is Colder Than Death and Wim Wenders's Summer in the City in 1970. Thomas Elsaesser $(2004,247)$ uses the concept of "experiential film" for narratives closer to film essays or documentaries, and this is also a matching expression for the most recent works of the German masters.

\section{Paleolithic Environment and Perception}

Werner Herzog's New Wave films can be classified, on the basis of the metaphors, symbolic forms, artistic tradition and mythology employed, with the trend of the so-called anti-film (Kovács 2005, 378; Elsaesser, 2004). These are characterized by the creation of a private mythology formed by the director's particular individualism, by parabolic form and a style built upon the means of expression of the senses of seeing, hearing, touching, and tasting. Herzog regards as the starting point of his films the physical presence of things, objects, or characters. The creative attitude by which he draws up a reality (for instance, by hauling a ship across a mountain in Fitzcarraldo) heralds in fact the reign of spirit as the manifestation of a constructive will. His artistic-existential conception is guided by the creation of original images and (dream)visions, in such a way that the basic questions of the art of film and his life conduct cannot be separated. This orientation leads him from the beginning to the recording of images of nature, to the representation of extraordinary optical phenomena or landscapes as filmic environment and the vehicle of mythical and symbolic content in a way unique in film production. Herzog's sensory experiences, his unique visionary imagery are a result of wandering and walking. The strange shooting locations, the variety 
of regions of the documentaries, the metaphoric poetry of natural phenomena are all born from this rite.

His most recent documentary shot about the around 400 paintings of Chauvet Cave in Ardèche valley in the south of France, discovered in 1994, is entitled The Cave of Lost Dreams. The more than 30,000 year-old animal depictions and symbols in relief decorate the uneven walls of several rooms and passages, and relate about the worldview and life circumstances of people in Europe living in the Upper Paleolithic period. This is the time of the last ice age (Würm) of the geologic time of Pleistocene, when the continent was largely covered with ice (reaching its highest cca. 25,000 BC), and the Homo sapiens had to live through this environmental change in the company of large mammals (bears, lions, rhinoceroses, horses). To the best of our knowledge, the earliest cave paintings are those found in La grotte Chauvet-Pont-d'Arc, and interdisciplinary historical, archeological, and anthropological researches prove that the objects, animal and human representations, and burial rites of humans living in the Upper Paleolithic period are evidence for a significant cognitive development. The hominids of the Pleistocene, adapting to the conditions of their environment, appropriated a self-preserving and reproductive behavior conditioned by the awareness of the interconnectedness of mental processes and ecological particularities, as well as the knowledge of one's space, one's habitat. Their orientation was not only determined by perception and movement, but also by their forming ability to treat their environment efficiently, and in accordance with their aims and worldview.

The Chauvet Cave is a place where the archetypal relationship of art and science can be experienced: the representations as creations of a mythical-mystical thinking are intertwined with an interested observation of natural phenomena. This early self-expression of the Homo sapiens cannot be connected to the phenomena of summer and winter solstice or spring and fall equinox because these only began to play a significant role later, in the period of the Neolithic and the Bronz Age. This cave of a worldwide significance is the place of the origin of art, the manifestation of human spirit, the birth of culture, where questions of the philosophy of culture and human existence are unavoidably present, as also, understandably, in the documentary of the German director.

The condition that Herzog was the only director who received the French government's permission to make a film determined the technical means that could be applied, which, in turn, resulted in a cinematic method built on the presence of multiple perceptions and their immersive effect on the viewers. The small 3D-camera, the spot-like illumination, the flashing lights give life to the 
contours, colors, movements of the animals, the appearance of relief-like shapes. This technique enhances the experience that the objects on the screen seem to dominantly move towards the spectator, and gain their optimal plasticity. This latter works as a duplicate, its intensity is due to the common sensory perception of the dimension of reliefs and the space of the prehistoric cave (for instance, the harmonic unity of the dynamics of the two fighting rhinoceroses and the unevenness of the cave wall). The environment becomes conspicuous because of the cave paintings which smoothly cover the stone shapes formed as the result of natural processes.

At the beginning of the film the camera focuses the spectator's attention to the natural formations of the location, the landscape - in accordance with the dominant motifs of Herzog's life-work and filmic narration - could even be the location of a Wagner opera or the subject of a German romantic painter. The surface of the dripstones and stones in the passages, the formal variety of solid and liquid matter and the painted or incised representation offers major stimulus for perception. The intensity of the spectacle, the cinematic illusion engages and at the same time blocks the sense of touch (the surfaces must not be touched). The complete silence required makes hearing "turn inwards:" to the sounds of bodily functions, the rhythm of heartbeat, the conscious perception of the body. This synchronized unity of perceptions is the foundation for the birth of this sublime moment of prehistoric art.

The methods used in the paintings reminiscent of phase diagrams recall the first experiments with moving images, eminently optical games and Eadweard J. Muybridge's motion series. It betrays Herzog's alienatingly ironic, cliché-less thinking that the image series as a cinematographic shadow-play does not draw on Plato's allegory of the cave, nor Vilém Flusser's analogy between Lascaux paintings and the beginnings of cinema; instead, he uses the playful humor of a fragment of an American musical to present them. Also, he renders relative the philosophical questions he necessarily poses by the following sequence or scene. His scenes presenting various extreme modes of perception justify this: the famous perfume maker tries to get information by his smell; the master of ancient musical instruments plays the never heard, only assumed prehistoric music; a researcher uses a spear to reconstruct a never seen, only imagined fighting technique.

The epilogue is an example of Herzog's most complex treatment of subtle, individual subtexts. Not far from the Chauvet cave there is a nuclear power plant which has its cooling water used for the heating of a tropical biosphere-reserve. Herzog and his team become aware of an extraordinary spectacle there: two 
albino crocodiles swimming in the water as each others' mirror image. The daring comparison suggests that, inasmuch as the albinos are prehistoric mutations, it may not be too unreal and unscientific to suppose that the man could also be something similar. Could it be still that we are not the surviving individuals of the evolution of the Homo sapiens, capable of reproduction and life, only some (accidental) mutations? Natural scientific research does not support this view, but on a metaphoric level and beyond it urges for further insight. The denouement of the film inspires the spectators to compare the purpose of two, very ancient and very modern, neighboring establishment of humans, the changed ecological conditions and their consequences, or the current world state of the Homo sapiens.

\section{Life-Dance against Death}

Similarly to Herzog, the experience of traveling and the continuity of movement is a dominant feature of Wim Wenders's modernist period. Tottering character, tumbling feet (Same Player Shoots Again, 1968), or a gaze at the outside world through the windscreen of a car (Summer in the City, 1970) are familiar motifs of his early films. In Wenders's opinion (1999, 83) walking and driving can be associated with the slowly passing perception of the camera, the long fade out takes on the meaning of "real" death. The simple factum brutum of his films is the passing-away at the end of the journey, but death is but an incidental fact. Wenders recalls Plato's allegory of the cave as an observation of perception: the traveler sees colorful spots, contours of forms, shadows passing by, which are reality to him. Discussions, encounters, and incidental events occurring during the voyage outline the phenomenon of life, the center of which is the problem of time. Can it be grasped, and in what way, if only the journey is the important turn in a person's life, while death is but an episode? Ultimately, Wenders tries, in all his films, to grasp the so-called "pure perception," the relations and contact modalities of motion and time, transforming them into image and sound. This is no different either in his documentary about a unique figure and phenomenon of the German art of dance.

Pina Bausch invented a form of self-expression which is not dance, theater, pantomime, or ballet, but all of these together, simultaneously. Her biographer, Jochen Schmidt (2002, 14-40) emphasizes that Bausch's art is the dance theater of the liberated body and spirit, of humanity, of the shaping of love, tenderness, and confidence between individuals, and of a dance language which enables the expression of a kind of communication that the other existing dance languages 
are no longer able to provide. Wenders's film betrays emotional involvement, sensitivity by dance, through which insignificant daily gestures, habitual forms of motion, or body postures become meaningful again. The motion picture and Bausch's wordless speech attracts attention to the values of our body, the natural dynamics of expression, the narration of inner stories.

The inspiration comes from the environment (Wuppertal), from the naturalartificial space of the individual, and the physical experience of the materials to be found there. The organic and inorganic matters of the landscape - earth, stone, water, air, vegetation - and the built environment of man - roads, stairs, geometric interiors - get in contact with human bodies. The enhanced physicalbiological presence, the works born from the chains of motions and gestures guide the attention to the problem of intellect, spirit, and body. The dances are placed within particular physical circumstances (such as, for instance, the four seasons as the framework for dancing in the film, both on the stage and in the landscape), while the mental connections, the affective-intellectual level expressed by the bodies addresses the mind.

The choreographies of Pina Bausch formulate the questions of guidance of one's life, the possibilities of freedom, the feelings of despair, joy, desire, or love, the relationship between sexes, man's relationship to action and labor, and the destruction of nature. Her art brings together the unity of spectacle-sound-motion of the dance with the space-time-plot continuum of short theater scenes, and this system encompasses the course of tragic and at times comic situations and human life situations. Motion pictures also possess these particularities, with the specificity that the continuity of space-time and motion is created by montage. This is the structure that Wenders enhances by 3D technology when creating Bausch's portrait in his own interpretation. This new means of expression helps him to intertwine his own methodology of film making with the characteristics of the choreographer's art and the perceptional aspects of reception.

The approach determined by the moving point of view was already present in his early films: the viewing direction of the camera placed in the inner space follows the possibly objective external location definition of the long shot and the bird's view. It happens similarly in this film, with the difference however that space creation in 3D becomes even more intense (the external image of the Wuppertaler Tanztheater with the characteristic suspension railway in the background is followed by a classic theater close-up showing the entire stage on ground floor level and part of the audience.) With this initial setting, Wenders poses again the theoretical questions which always interest him: the problem of 
perception by film and the role of stories (1999, 185-195). It is a necessary step for the expression of Bausch's art, characterized by ignoring the limits of theater, dance, and film, and insuring the free flow of their means and interpretations.

Besides the novelty of seeing and the enhancement of the spatial motion dimension of the spectacle, Wenders had to build upon the particularities of the other senses as well in order to be faithful to the world of the German choreographer and his own (theoretical) investigations: he also engaged hearing, haptic and bodily perception so as to make the viewer's implication more intense. This complex of perceptions works most convincingly if it is assisted and enforced by the compositional structure of the film. The audiovisual framework of the film is set by the metaphorical and semantic meanings of the four seasons: the dancers walking in a single line through the space of the stage, then over the ridge of a green hill among statues, communicate by signs the effect of periodic changes on the body. Since Bausch could no longer be there on the shooting, she dominates the film as a medial imprint, on photo and archival footage, as well as through a monologue in the background of the dancers' portraits. Wenders employs the form of film within film, to which he associates the structure of theater within theater and dance within dance. This complex structure functions on the one hand as auto-textual mirroring - let's think of the films Lightning over Water (1980) and The State of Things (1982) - and on the other hand it attempts at grasping the essence of creative process by the multiplication, with the fact of death in Bausch's "one-minute" sketches, and with the metaphor of passing away of the ending film. Péter Esterházy $(2002,9)$ has a pertinent formulation: "Art, poetry is itself something that is embodied in a man, the happy recognition that art, although having no purpose, is still good for something - it speaks, it speaks of our existence as nothing else can.”

Wenders's return to a filmic vision of Vertov's influence lies on structural grounds, logically developing from the new technology of spectacle, while highlighting its hindrances and impossibilities emphasized precisely by this medial awareness. He continues not with the avoidance, but the acceptance of this paradox, and revives a film production practice, familiar ever since the avant-garde, that film is an art which addresses the individual as a whole, and requires a certain education of senses. The characters of his narrations experience extraordinary situations, the dissolution of which is related to seeing and observation, because they have to realize that "they suddenly have to see things differently" (Wenders 1999, 192). The dilemma is whether auteur film exists at all, devoid of technical means and influences, disrupted from, or perhaps going together with, the self-shaping contradictions of the narratives, exempt from 
the constraint of meaning creation, based on pure perception. With his film on Bausch, Wenders attempts to reformulate his theoretical questions.

The Wuppertal Dance Theater has two choreographies as its trademarks: Stravinsky's ballet The Rite of Spring, and the piece entitled Café Müller, in which Bausch herself performed as a dancer. In the latter's case, the commentary attached to the archival footage presented in the film informs about a creative mode which mirrors the subtleties of perception: that is to say, whether the feeling and perception mediated by movement with eyes closed becomes complete if the dancer's eyes under the closed eyelids look ahead or down. This emphasis of Wenders, besides nuancing the extraordinary creativity and sensibility of the choreographer, drives the attention away from that what is visible and that what is seen precisely by the voluntary limitation of seeing, and directs it towards the sad-lyrical arias of Purcell and towards body touching. The mutually unifying presence of the spectacle, the music, and body perception was first achieved in 1975, in the choreography composed for Stravinsky's Le Sacre du Printemps. Bausch employs the various matters or elements (fire, water, wind, stone, earth, landscape, vegetation) in a way different from the usual forms of dance: here, the whole stage is covered with brown turf poured out from waste bins, with which the dancers permanently interact. The body lying on the purple drapery in the film, the motion forms of men and women create the tension on the rectangular stage in a diagonal composition. The choreography expresses the ancient rite of sacrifice from the point of view of the chosen victim, with the emotional-sensual charge of fear, pity, sexuality, and corporeality. The 3D camera of the film is the other gaze which takes on the position of the viewer, who helplessly allows to be drawn into the plot, as if by a vacuum, by the dramatic expression of the woman's close-up and the diagonal movement of the dancers.

The centralization of the material reality, the perception and self-expression of the body is a permanent consistency in Wenders's creative method. It recalls certain film theory associations: particularly those which consider a film a kind of contact, an encounter with the other (such as, e.g. intercultural cinema), and also those which refer to the skin's role in perception, to the haptic experience (Casetti 1999; Elsaesser-Hagener 2007). Wenders's film does not commit itself to either of the two; however, nor does it go deeper into any one of these. Much rather, it looks for a common set of these: it enforces intercultural encounters and communication possibilities by a variety of languages and foreign speech, as well as profound inner connections deriving from a sense and perception of the external changes and vulnerability of the skin and the human body at large. 


\section{Conclusion}

The documentaries under scrutiny here, created by the two renowned directors of the German new wave, are based on the mutual relationship of sensory experiences triggered by the sense of seeing-hearing-touching and by body perception. This goal was attained as a result of the subject matter and the means of expression applied, as well as the viewers' active participation, by their creation of sensorial cinema, which treats the relationship of the creator, the work of art, and the viewer as a unitary whole, in a complex and balanced manner. Ever since the time of avant-garde filmmaking building upon both the theoretical and practical side of the film, these types of moving images have really been employed in the field of feature- and documentary filmmaking.

Ultimately, Wenders's film called Pina tackles the changes that have occurred about the particularities in perception together with the application of technology and the most recent technical instruments. According to the evidence of mainstream films and expectations shaped by these, the 3D film primarily enhances optical features with the spatial composition and motion dimension of the spectacle, heralding thus the primacy of vision. This eye-centered conception, otherwise very efficient, proves to be overly one-sided for the German directors when they elaborate on the basic matters of art and culture, and the first known visual signs of the life of man. The creative method is shaped and altered, the creative means are being enriched in response to a necessity and constraint of some sort. Wenders's interpretation of Bausch's art and Herzog's prehistoric cave presentation primarily exploits the multiple interactions of perception, which may bring about the formation of a cinematography which disrupts itself from technology, frees itself from influences, and abandons the narration of stories.

This is how things may have been in the time of the earliest visual signs, the first images, and from which the power and cultic function of images may have emerged. We are not aware of the meanings and practical purposes that the prehistoric man may have given to the first visual signs, but for contemporary people these signs do have a historic meaning, intertwined with the concept of art. The history of art engages its beginnings as all historical knowledge, and declares its diachronic character by spatial and temporal references, and the prevalence of the old form and style by new experiments. The relationship of the prehistory of the moving image and digital image creation is an appropriate example for this process. Our previously shaped concepts of time and space, causality or narration are all doomed to failure, and we can hardly speak about evolution 
in art when faced with the primordial visual expression seen in Herzog's film. The two documentaries reveal that sometimes it would make much more sense to think about art not as a linear, evolutionary process, but as a cyclical system.

\section{References}

Arnheim, Rudolf. 1985. A film mint múvészet [Film as Art]. Budapest: Gondolat Kiadó.

Balázs, Béla. 1984. A látható ember [The Visible Man]. Budapest: Gondolat Kiadó. Bíró, Yvette. 2003. Nem tiltott határátlépések [Not Forbidden Trespassings]. Budapest: Osiris Kiadó.

Casetti, Francesco. 1999. Theories of Cinema, 1945-1995. Austin: University of Texas Press.

Csabai, Márta and Erős Ferenc, eds. 2002. Test-beszédek: köznapi és tudományos diskurzusok a testról [Body-speeches: Everyday and Scholarly Discourses on the Body]. Budapest: Új Mandátum.

Dúll, Andrea. 2009. A környezetpszichológia alapkérdései. Helyek, tárgyak, viselkedés [Basic Questions of Environmental Psychology. Places, Objects, Behavior]. Budapest: L’Harmattan Kiadó.

Eisner, Lotte H. 1994. A démoni filmvászon [The Demonic Filmscreen]. Budapest: Magyar Filmintézet-Filmvilág-Szellemkép.

Elsaesser, Thomas. 2004. A német újfilm [The German New Wave]. Budapest: Palatinus Kiadó.

Elsaesser, Thomas and Malte Hagener. 2007. Filmtheorie zur Einführung [Introduction to Film Theory]. Hamburg: Junius Verlag GmbH.

Freyermuth, Gundolf S. 2011. Der Big Bang digitaler Bildlichkeit. 3D im Kontext der neuzeitlichen Mediengeschichte [The Big Bang of Pictures. $3 D$ in the Context of New Media History]. http://www.schnitt.de/211,0059,01 Last accessed at 2011. 12. 01.

Gibson, James J. 1966. The Senses Considered as Perceptual Systems. Boston: Houghton-Miffin.

Sekuler, Randolph and Robert Blake. 2004. Észlelés [Perception]. Budapest: Osiris Kiadó.

Kovács, András Bálint. 2005. A modern film irányzatai [Trends of the Modern Film]. Budapest: Palatinus Kiadó.

Kracauer, Siegfried. 1964. Az érzékszervekre gyakorolt hatás [The Effect on the Senses of Perception]. In A film elmélete I-II. A fizikai valóság feltárása [The 
Theory of Film I-II. Discovery of the Physical Reality]. Budapest: Filmtudományi Intézet.

Kracauer, Siegfried. 1999. Von Caligari zu Hitler: Eine psychologische Geschichte des deutschen Films [From Caligari to Hitler: a Psychological History of German Cinema]. Frankfurt am Main: Surkamp Verlag.

Moholy-Nagy, László. 1978. Festészet, fényképészet, film [Painting, Photography, Film]. Budapest: Corvina Kiadó.

Müller Péter, P. 2009. Test és teatralitás [Body and Theatrality]. Budapest: Balassi Kiadó.

Pethő, Ágnes. 2003. Múzsák tükre [Mirror of the Muses]. Csíkszereda: Pro-Print Kiadó.

Popper, Karl R. 1998. Test és elme: Az interakció védelmében [Body and Mind. For the Defence of Interaction]. Budapest: TypoTex Elektronikus Kiadó.

Schmidt, Jochen. 2002. Pina Bausch - Tanzen gegen die Angst [Pina Bausch Dancing versus Fear]. München: Econ Ullstein List Verlag.

Sobchack, Vivian. 2004. What My Fingers Knew: The Cinesthetic Subject, or Vision in the Flesh. In: Carnal Thoughts. Embodiment and Moving Image Culture. Berkeley, CA: University of California Press.

Wenders, Wim. 1999. Írások, beszélgetések [Writings, Discussions], ed. Zalán Vince. Budapest: Osiris Kiadó. 